\title{
Budaya Populer Jepang di Indonesia : Catatan Studi Fenomenologis Tentang Konsep Diri Anggota Cosplay Party Bandung
}

\author{
Oleh: Antar Venus \& Lucky Helmi ${ }^{1}$
}

\begin{abstract}
The research is about self concept in the relations with popular culture, that in the youth cultures has been done since 30 years ago. The term of self concept which becomes focus on this paper was defined by Rogers as how someone see and feel himself. This paper is based on limited introduction research of phenomenology about self concept of Cosplay Party members in Bandung City. The amount of informants is four and the frequency of interview just twice. The result of the research shows that informants have different background and have positive self concept. They involve in costume player started with their hobby in watching anime and join in Cosplay because of the same of value between them.
\end{abstract}

Key words : self concept, phenomenology, Cosplay

Saya Bergaya, Maka Saya Ada....

\section{Pengantar}

Ragam budaya populer Jepang yang kini 'populer' di Indonesia meliputi banyak bentuk mulai dari Film, Musik, anime, manga/komik, hingga fashion atau lebih tepatnya gaya pakaian kaum muda Jepang. Cacatan studi fenomenologis yang disajikan dalam makalah ini tidak dimaksudkan untuk menyoroti seluruh bentuk budaya populer Jepang di atas. fokus tulisan ini lebih pada fenomena gaya pakaian kaum muda Jepang atau lebih populer dengan isilah J-Style atau J-Fashion.

J-fashion yang merebak dikalangan kaum muda kelas menengah perkotaan Indonesia,, khususnya Bandung dan Jakarta, lebih mewujudkan

1 Antar Venus, Dosen Jurusan Manajemen Komunikasi Unpad / Lucky Helmi alumnus Fikom Unpad. 
dirinya dalam bentuk costum playing atau semacam permainan kostum yang dikenakan pada berbagai event cosplay atau penampilan busana bersama di suatu tempat berkumpul (dalam istilah mereka disebut tempat mejeng). Para Costum Player ini umumnya bukan pelaku individual melainkan anggota komunitas cosplay tertentu. Oleh karena gaya pakaian mereka yang sangat unik, para costum player ini seringkali menjadi pusat perhatian sekaligus pusat pertanyaan masyarakat tentang apa, siapa dan bagaimana mereka sampai bergaya pakaian unik seperti itu. Untuk menjawab pertanyaan masyarakat tersebut Penulis tertarik untuk mengkaji fenomena cosplay ini dengan melakukan penelitian pendahuluan dengan pendekatan fenomenologi. Berikut adalah paparan teoritis dan hasil temuan lapangan tentang konsep diri anggota Komunitas cosplay party. Pembahasan dimulai dengan mengamati fenomena budaya populer Jepang di Indonesia, lalu mengkaji relevansi studi konsep diri dengan budaya populer kaum muda, dan terakhir disajikan hasil penelitian fenomenologi tentang konsep diri anggota komunitas Cosplay Party Bandung.

\section{Fenomena Budaya Populer Jepang di Indonesia}

Budaya adalah konsep pokok dalam kajian antropologi. Konsep ini biasanya mencakup aspek-aspek seperti pengetahuan, teknologi, nilai, keyakinan, kebiasaan, dan perilaku yang umum bagi manusia. Menurut Marshall (1998) pada masyarakat yang sederhana biasanya hanya terdapat satu bentuk budaya utuh (integrated culture) yang diusung oleh semua anggota masyarakat. Sedangkan pada masyarakat yang kompleks entitas budaya ini memiliki lapisan yang banyak meliputi budaya dominan dan beragam sub-subbudaya.

Salah satu pembedaan terpenting dalam masyarakat yang kompleks adalah perbedaan antara budaya populer (popular Culture) dan budaya tinggi (High culture). Budaya tinggi biasanya meliputi musik klasik, syair, tarian, lukisan hingga novel-novel serius, dan berbagai produk budaya lainnya yang diapresiasi oleh sejumlah kecil orang terdidik atau berstatus sosial tinggi. Disisi lain budaya populer (seringkali disamakan dengan budaya massa) jauh lebih menyebar dan mudah diakses oleh semua orang. Kepentingan pokok dari budaya populer ini adalah untuk hiburan dan wujudnya didominasi oleh musik rekaman, komik, film, olah raga dan gaya berpakaian (fashion). Menurut Sullivan, dkk (1996) segala produk budaya yang secara sengaja dibuat sesuai selera orang kebanyakan dapat disebut sebagai budaya populer. Oleh karena itu secara sederhana Sullivan 
mengartikan budaya populer sebagai bentuk budaya yang disukai orang banyak.

Di Jepang istilah budaya populer sulit dicari padanannya. Menurut Hidetoshi Kato (Powers \& Kato, 1989) istilah ini dapat disamakan dengan terminologi Taishu Bunka. Namun penyamaan ini juga bukannya tanpa masalah karena pengertian Taishu Bunka sendiri adalah budaya massa (Mass culture). Terlebih konsep Taishu bunka sendiri bersifat egaliter dan tidak membedakan antara entitas massa dan elite atau antara orang berstatus sosial tinggi dan rendah. Penulis tidak ingin memperpanjang perdebatan tentang kedua konsep tesebut, karena fokus makalah ini bukan pada persamaan kedua kata diatas melainkan pada konsep diri kaum muda indonesia yang menjadi pencinta budaya populer jepang.

Budaya populer Jepang atau selanjutnya disingkat J-pop umumnya meliputi pertunjukan televisi, Film, comic/manga, anime, musik, dan fashion ${ }^{2}$. Dari semua ini yang paling populer di indonesia adalah anime, manga, dan fashion atau gaya pakaian anak muda Jepang. Para pengguna gaya pakaian Jepang ini dalam istilah ekspresifnya sering disebut sebagai costum player (Cosplay). Penggunaan istilah ini mengindikasikan bahwa pemakaian kostum tersebut lebih cenderung bukan sebagai pakaian seharihari tapi lebih pada event pertunjukan atau penampilan bersama.

Costume Player di Jepang awalnya berasal dari gaya para tokoh-tokoh komik yang sepertinya tidak mungkin ditiru. Namun anak- anak muda Jepang berinisiatif untuk mencoba gaya-gaya di komik tersebut. Dari sanalah gaya anak muda Jepang berkembang dan mulai berbeda-beda sesuai keinginan masing-masing individu. Anak-anak muda yang menganut gaya ini dapat dijumpai di daerah Shibuya dan Harajuku. Mereka tak hanya bergaya ala tokoh kartun seperti Hello Kitty, tapi juga Marlyn Manson, Hip Hopers, dan gaya-gaya lain yang tidak kalah unik untuk dilihat. Tidak jarang mereka memodifikasi baju seragam; berlengan pendek seperti mini skirt, rok yang mini, dan kaos kaki gombrong dari pangkal betis sampai kemata kaki. Mereka biasanya mangkal di Shibuya sehingga disebut Kogal. Ada lagi yang lebih ekstrim yang disebut Gals atau Gyaru. Gals adalah komunitas yang sadar fesyen, selalu mengikuti perkembangan, sering pergi ke salon untuk mengubah penampilan mulai dari mengecat rambut, tindik anting, bahkan tanning (proses penghitaman kulit). ${ }^{3}$

2 Patrick Macias, East meets West (You Know The Rest) dalam Japan Edge, Annete Roman (ed). 1999.

3 www.matabaca.com, 2006 
Terdapat berbagai macam aliran cosplay di antaranya Cosplay Japanese Star atau Cosplay J-Star yang terbagi menjadi dua aliran, yaitu J-pop dan J-rock. Cosplay Anime yang pakaiannya terinspirasi dari tokoh animasi. Cross Play dimana perempuan berdandan seperti lelaki dan lelaki berdandan seperti perempuan. Cosplay Original, yaitu pengguna kostum ala Jepang yang desainnya sudah dimodifikasi dengan imajinasi sendiri, tetapi tetap membawa ciri utama dari gaya aliran tertentu misalnya, membuat kostum samurai digabungkan dengan obi atau sabuk kimono, gothic, dan Harajuku style. Ada juga aliran Tokusatsu yang menggunakan kostum superhero Jepang seperti Power Ranger, dan aliran Ganguro yang mengadopsi rias wajah tokoh pop Jepang, biasanya mereka mencoklati wajah mereka yang pias (tanning) dan menggunakan riasan dengan warna-warna yang kontras dengan kulit mereka seperti lipstik dan perona mata putih. ${ }^{4}$

J-fashion dalam wujud Cosplay muncul di Indonesia pada awal tahun 2004. mula-mula di Jakarta, lalu menyebar ke berbagai kota besar di Indoensia. Sebelum Cosplay populer, Anime dan Manga telah terlebih dahulu menjadi trend Budaya populer Jepang yang diminati kaum muda perkotaan Indonesia sepanjang mulai paruh kedua tahun 1990-an hingga tahun 2000. ${ }^{5}$.

Popularitas J-fashion di Indonesia dikembangkan lewat berbagai saluran komunikasi yang ada, mulai saluran personal yang melibatkan tokoh-tokoh selebriti seperti Agnes Monica, Indra Bekti, Duo Ratu (Maia Ahmad dan Mulan Kwok), dan personil Band J-Rock, hingga saluran elektronik (terutama televisi) dan pertemuan publik seperti yang digalang oleh The Japan Foundation lewat festival Ikiteru Harajuku pada bulan september 2006 yang lalu. Lewat saluran ini pengaruh J-style merembes kedalam kehidupan kaum muda kelas menengah perkotaan Indonesia.

Menurut laporan Kompas (24/9/06) dan H.U. Pikiran Rakyat (16/3/04), pada saat ini komunitas pencinta J-fashion telah muncul diberbagai kota besar Indonesia khususnya Bandung dan Jakarta. Di Kota Bandung sendiri jumlah komunitas yang muncul diperkirakan lebih dari dua puluh dengan jumlah anggota yang mencapai ratusan orang. Diantara komunitas tersebut adalah Cosplay party, Ulets, dan Kansai. Cosplay party merupakan komunitas yang paling dikenal diantara berbagai komuitas yang ada. Hal

\footnotetext{
Kompas, Minggu, 16 April 2006:23

Pikiran Rakyat, 16 April 2006

Wawancara dengan Andi, Pengelola Harajuku Ciwalk, pada tanggal 2 januari 2007.
} 
ini karena seringnya anggota komunitas ini tampil di media cetak sebagai reperesentasi cosplay di Bandung. Di luar itu, aktivitas komunitas ini juga tergolong padat karena partisipasi anggota-anggotanya yang tinggi dalam berbagai event cosplay yang diselenggarakan di Bandung dan Jakarta.

\section{Relevansi Konsep Diri dalam Kajian Budaya Populer}

Penelitian tentang konsep diri dalam kaitannya dengan budaya populer dikalangan anak muda (the youth cultures) telah dilakukan sejak tiga puluh tahun yang lalu. Hal ini misalnya dapat dilihat dari penelitian Morris Rosenberg tentang Black and White SelfEsteem (1972) dan penelitian yang bertajuk Conceiving the self tahun 1979 (Marshall, 1998). Buku Mike Brake, The Sociology of Youth Culture and Youth Subculture Juga mengupas keterkaitan budaya kaum muda ini dengan konsep diri pengusungnya (Marshall, 1998). Dengan demikian mengaitkan antara konsep diri dengan budaya populer kaum muda sebenarnya memiliki tradisi yang panjang dan dasar pemikiran teoritis yang kuat (strong theoritical rationale). Kenyataan ini juga menujukkan bahwa mengkaji konsep diri dalam menganalis budaya populer kaum muda menjadi sangat penting dan memberikan wawasan tentang bagaimana kaum muda merespon dan memaknai budaya populer yang sedang mereka hadapi berdasarkan konsep diri yang dimiliki.

Istilah Konsep diri yang dijadikan fokus pembahasan dalam makalah ini diartikan Rogers, tokoh psikologi fenomenologi, sebagai sebagai cara seseorang memandang dan merasakan dirinya sendiri (Burns, 1993). Watson \& Hill (2000) memberikan batasan yang senada, dengan menegaskan konsep diri sebagai keseluruhan gambaran seseorang tentang dirinya sendiri. Gambaran ini mencakup keseluruhan persepsi individu tentang karakter dirinya, citra tubuh, kemampuan yang dimiliki, emosi, serta hubungan dirinya dengan orang lain. Konsep diri ini umumnya dipandang memiliki dua dimensi yakni Citra diri (self-image) dan dan evaluasi diri (self esteem). Citra diri merupakan bagian gambaran (descriptive part) tentang konsep diri. Ini adalah gambaran yang dimiliki seseorang tentang dirinya sendiri. Sedangkan Harga diri adalah bagian evaluatif (evaluative part) dari konsep diri yang menunjukkan bagaimana seseorang mersa tentang dirinya.

Konsep diri juga dipandang sebagai Gambaran yang bersifat personal (pribadi), dinamis dan evaluatif. Dengan demikian Pengertian seseorang mengenai dirinya dapat berubah dan berkembang sejalan dengan akumulasi 
pengalaman seseorang dalam berinteraksi dengan lingkunganya. Disini tampak bahwa persepsi kita tentang bagaimana orang lain memandang kita, akan turut menentukan bagaimana kita membentuk konsep diri. Dalam istilah Cooley (Burns, 1993) hal ini disebut dengan istilah The looking glass self yang maksudnya konsep diri individu secara signifikan ditentukan oleh apa yang ia pikirkan tentang pikiran orang lain mengenai dirinya. .

Di sisi lain kita juga seringkali berupaya mempengaruhi pandangan orang lain tentang diri kita melalui pengelolaan kesan diri (self impresion management). Umpan balik yang diterima melalui pengelolaan kesan atau presentasi diri ini akan memampukan kita mengevaluasi dan membentuk citra diri kita yang pada gilirannya menentukan bagaimana kita bertindak, berhubungan dan mengevaluasi berbagai peristiwa di sekitar kita (Burns, 1993). Dalam konteks ini Fitts (Agustiani, 2006) mengatakan bahwa konsep diri berpengaruh kuat terhadap tingkah laku seseorang. Dengan mengetahui konsep diri seseorang, akan lebih mudah meramalkan dan memahami tingkah laku orang tersebut. Pada umumnya tingkah laku individu berkaitan dengan gagasan-gagasan tentang dirinya sendiri.

Oleh karena sifatnya yang melekat pada diri seseorang maka konsep diri ini akan terus dibawa-bawa sepanjang perjalanan hidup seseorang. Implikasinya Konsep diri kita akan terlibat dalam segenap area kehidupan kita, bagaimana kita berbuat, menetapkan tujuan, berperilaku dalam status sosial tertertu, hingga bagaimana kita berperilaku dalam hal busana. Keputusan seseorang untuk berbusana dengan cara tertentu merupakan cerminan dari konsep diri orang tersebut. Jadi untuk mengetahui mengapa seseorang berpakaian dengan cara tertentu dapat diketahui dengan mengkonstruksi konsep diri orang yang bersangkutan. Pada dasarnya seseorang tidak ingin melakukan sesuatu yang tidak seseuai dengan konsep dirinya, kalaupun terjadi penyimpangan maka akan muncul semacam ketidaknyamaan kognitif antara apa yang dia yakini dengan apa yang dilakukannya.

William H. Fitts (Agustiani, 2006) mengemukakan bahwa konsep diri merupakan aspek penting dalam diri seseorang, karena konsep diri seseorang merupakan kerangka acuan (frame of reference) dalam berinteraksi dengan lingkungan. Ia menjelaskan konsep diri secara fenomenologis, dan mengatakan bahwa ketika individu mempersepsikan dirinya, bereaksi terhadap dirinya, memberikan arti dan penilaian serta membentuk abstraksi tentang dirinya, berarti ia menunjukkan suatu kesadaran diri (self awaerness) dan kemampuan untuk keluar dari dirinya sendiri untuk melihat dirinya 
seperti yang ia lakukan terhadap dunia diluar dirinya. Diri secara keseluruhan (total self) seperti yang dialami individu disebut juga diri fenomenal. Diri fenomenal ini adalah diri yang diamati, dialami, dan dinilai oleh individu sendiri, yaitu yang ia sadari. Keseluruhan kesadaran atau persepsi ini merupakan gambaran tentang diri atau konsep diri individu.

Dalam pandangan Rosenberg (Marshall, 1998), konsep diri bukanlah kenyataan yang tunggal. Dalam diri manusia setidaknya terdapat tiga macam diri yakni; the extant self ( gambaran diri kita seperti yang dialami), the desired self (gambaran diri kita yang ita kehendaki), dan the presenting self ( yakni diri yang kita tampilkan pada situasi tertentu atau ketika berinteraksi dengan orang lain).

Literatur psikologi juga mengenal pembagian konsep diri dalam kategori positif atau negatif walaupun disadari tidak ada orang yang sepenuhnya berkonsep diri positif atau negatif. Dalm konteks konsep diri positif. D. E Hamachek (Burns, 1993) menyebutkan sebelas karakteristik orang yang memiliki konsep diri positif:

1. Ia meyakini betul-betul nilai-nilai dan prinsip-prinsip tertentu serta bersedia mempertahankannya, walaupun menghadapi pendapat kelompok yang kuat. Tetapi, dia juga merasa dirinya cukup tangguh untuk mengubah prinsip-prinsip itu bila pengalaman dan bukti-bukti baru menunjukkan dia salah.

2. Ia mampu bertindak berdasarkan penilaian yang baik tanpa merasa bersalah yang berlebih-lebihan, atau menyesali tindakannya jika orang lain tidak menyetujui tindakannya.

3. Ia tidak menghabiskan waktu yang tidak perlu untuk mencemaskan apa yang terjadi besok, apa yang telah terjadi di waktu yang lalu, dan apa yang sedang terjadi di waktu sekarang.

4. Ia memiliki keyakinan pada kemampuannya untuk mengatasi persoalan, bahkan ketika ia menghadapi kegagalan atau kemunduran.

5. Ia merasa sama dengan orang lain, sebagai manusia tidak tinggi atau rendah, walaupun terdapat perbedaan dalam kemampuan tertentu, latar belakang keluarga, atau sikap orang lain terhadapnya.

6. Ia sangggup menerima dirinya sebagai orang yang penting dan bernilai bagi orang lain, paling tidak bagi orang-orang yang ia pilih sebagai sahabatnya.

7. Ia dapat menerima pujian tanpa berpura-pura rendah hati, dan menerima penghargaan tanpa merasa bersalah. 
8. Ia cenderung menolak usaha orang lain untuk mendominasinya.

9. Ia sanggup mengaku kepada orang lain bahwa ia mampu merasakan berbagai dorongan dan keinginan, dari perasaan marah sampai cinta, dari sedih sampai bahagia, dari kekecewaan yang mendalam sampai kepuasan yang mendalam pula.

10. Ia mampu menikmati dirinya secara utuh dalam berbagai kegiatan yang meliputi pekerjaan, permainan, ungkapan diri yang kreatif, persahabatan, atau sekedar mengisi waktu.

11. Ia peka pada kebutuhan orang lain, pada kebiasaan sosial yang telah diterima, dan terutama sekali pada gagasan bahwa ia tidak bisa bersenang-senang dengan mengorbankan orang lain.

Karakteristik konsep diri positif menurut Hamacheck ini selanjutnya akan digunakan sebagai kerangka untuk mengevaluasi apakah para informan penelitian memiliki konsep diri yang positif atau tidak.

\section{Fenomenologi Konsep Diri Anggota Komunitas Cosplay Party}

Kajian fenomenologis tentang Konsep diri anggota komunitas Cosplay Party Bandung ini merupakan penelitian pendahuluan yang bersifat terbatas. Jumlah informan dalam penelitian ini hanya empat orang dan frekuensi wawancara yang dilakukan untuk setiap informan hanya dua kali. Sementara bila kita mengacu pada format penelitian fenomenologis yang ditetapkan Cresswell (1998), jumlah informan diharap mencapai sepuluh orang meskipun hal ini juga harus mempertimbangkan tingkat kejenuhan data (saturated data). Sedangkan wawancara yang dilakukan diharapkan lebih dari dua kali untuk memperlihatkan konsistensi, kesahihan, dan kedalaman data.

Penelitian ini dimaksudkan untuk memahami secara penuh konsep diri anggota komunitas Cosplay party. Dengan demikian penelitian ini lebih bersifat deskriptif dalam arti berupaya menggali informasi sebanyak mungkin dari sudut pandang anggota komunitas untuk menjawab pertanyaan "apa' dan 'bagaimana". Jadi penelitian ini tidak ditujukan untuk mengukur (measuring) sesuatu yang berkenaan dengan hubungan atau pengaruh apapun dari konsep diri terhadap perilaku anggota cosplay party, melainkan untuk menemukan (discovering) tentang apa dan bagaimana anggota-anggota Cosplay Party memandang dirinya dan memaknai keterlibatannya dalam komunitas cosplay party. Dengan alasan diatas maka metode yang tepat digunakan adalah fenomenologi. 
Penelitian ini dilakukan pada tanggal 12 hingga 26 Januari 2007, dengan melibatkan empat responden yakni : Valentina Damiana alias $\mathrm{Ru}$, Dirck Julian, Khairani alias Aira dan Patricia alias Kuo. Keempat informan ini adalah anggota komunitas Cosplay party Bandung yang berdiri pada pada 20 februari 2005. Pengumpulan data dilakukan lewat wawancara mendalam (indepth interview). Sedangkan validitas data dilakukan dengan menggunakan teknik Triangluasi.

Pertanyaan penelitian yang diajukan adalah sebagai berikut; Bagaimanakah latar belakang kehidupan anggota komunitas cosplay party? Bagaimanakah konsep diri anggota komunitas tersebut? Bagaimanakah mereka mengekspresikan diri dalam cosplay event dan dalam kehidupan sehari-hari? dan Bagaimanakah pengaruh nilai-nilai cosplay terhadap konsep diri anggota komunitas?

Berikut adalah hasil penelitian yang disusun sesuai daftar urut pertanyaan diatas;.

\section{Latar Belakang Informan:}

1. Valentina Damiana alias $\mathrm{Ru}$, wanita $\mathrm{u}$ sia sekitar 20 tahun mahasiwa jurusan Planologi Itenas bandung. berasal dari keluarga kecil, memiliki seorang kakak perempuan yang beda usianya lima tahun. Tidak terlalu dekat dengan kakaknya dibandingkan dengan kedua orangtuanya, khususnya sang mama. Ru biasa bercerita apa saja pada mamanya. Ayahnya bersuku jawa dan Ibunya Jawa-Sunda. Dirumah, orangtuanya mendidik Ru dengan adat Jawa yang mementingkan tata krama dan selalu mengingatkan kodratnya sebagai perempuan. Tertarik anime sejak di Sekolah dasar. Di SMA bertemu teman-teman yang juga menyukai anime sehingga mengukuhkan ketertarikannya pada berbagai hal berbau Jepang. Tiga orang terpenting yang berpengaruh bagi Ru adalah Orang Tua/keluarga, teman dan pacar.

2. Dirck Julian, Mahasiswa fakultas sastra jurusan bahasa Jepang semester VI. Usia 19 tahun. Sulung dari tiga bersaudara. Dua adiknya hadir setiap kurun lima tahun sejak kelahirannya. Bentuk wajah Dirck berasal dari gen ayahnya yang masih memiliki keturunan Ambon hanya saja Dirck berkulit putih tidak seperti kebanyakan orang Ambon. Kulitnya ini titisan dari sang ibu yang berdarah Sunda. Seperti layaknya kakak adik, hubungan Dirck dan saudara-saudaranya juga sering diwarnai pertengkaran-pertengkaran kecil karena hal yang sepele. Ayahnya 
merupakan orangtua yang tegas, sedangkan sang ibu cenderung memberikan kebebasan pada anak-anaknya dalam melakukan sesuatu, hanya saja tetap harus bertanggungjawab. Dirck saat ini merasa lebih dekat dekat teman-temannya daripada keluarganya. Di kampus Dirck memiliki teman se-geng yang berjumlah 12 orang termasuk dirinya yang terdiri dari 5 laki-laki dan 7 perempuan. Hubungan mereka sangat dekat. Ketertarikan Dirck akan Jepang berawal dari hobinya yang suka membaca komik dan menonton kartun Jepang sejak kecil. Pokoknya tiada hari tanpa membaca komik, bahkan Dirck menjadikan membaca komik sebagai kegiatan wajib sebelum tidur.

3. Khairani alias Aira tapi di rumah ia biasa dipanggil Aya. Usia 19 tahun. Mahasiswa di STBA (Sekolah Tinggi Bahasa Asing) jurusan Bahasa Jepang. Bekerja di cafe Musume sudah tiga bulan. Hobi chatting. Berasal dari keluarga keturunan Palembang-Sunda. Namun dari kecil ia tinggal dan dibesarkan di Bandung tempat ibunya berasal, pernah ke Palembang sekali ketika usianya setahun. Dengan keluarga di Bandung Aira dan saudara-saudaranya tidak terlalu dekat, paling bila bertemu hanya ngobrol biasa saja. Keluarga Aira sudah tidak utuh lagi, ayahnya meninggal dunia tiga tahun yang lalu. Saat ini Aira tinggal berlima dengan ibu, kakak laki-laki, adik perempuan dan neneknya. Anaka ketiga dari empat bersaudara. Beda Aira dengan kakak pertamanya 12 tahun, dengan yang kedua 6 tahun, dan dengan si bungsu 3 tahun. Di keluarganya Aira lebih dekat dengan Nurul sang adik, mungkin karena sama-sama perempuan dan rentang usia mereka berdua juga tidak terlalu jauh. Sejak kecil Aira dan saudara-saudaranya diajar disiplin oleh kedua orangtuanya. Tak jarang bila mereka nakal hukumannya dipukul atau dikunci di kamar mandi. Selain disiplin orangtua Aira juga cukup terbuka, mereka membebaskan anak-anaknya untuk melakukan sesuatu, mereka hanya memberi nasihat, setiap keputusan tetap berada di tangan anak-anak.

4. Patricia alias Kuo. Mahasiswa Universitas Maranatha jurusan Desain. Wanita berusia 20 tahun ini besar di Bandung dari keluarga campuran Ibu Melayu-Medan dan Ayah bersuku Jawa. Hobi bermain para-para versi Jepang (Sejenis tarian). Bercita-cita menjadi penulis komik dan dubber. Saat ini Kuo juga menjadi vokalis di droup Tabasco. Dari TK sudah menyukai gambar-gambar anime, dan membaca komik Astroboy dan Candy-canyd. Sekarang merasa pas terjun di dunia desain. Awalnya orangtua tidak mendukungg, jadi karya gambarnya ada yang 
dirobek, dibakar, dibuang. Akhirnya mereka menyerah karena keliatan aku serius dan jalan terus. Kuo yang masih memiliki darah keturunan Hamengkubuwono I dari papanya mengaku waktu kecil ia sama sekali tidak dekat dengan keluarganya karena papanya sering bekerja di luar kota bahkan mereka saling menempelkan memo untuk berkomunikasi. Perubahan itu terjadi sejak kakeknya meninggal, ayahnya harus meneruskan usaha keluarga di Bandung. Berangsur-angsur keluarganya menjadi seperti layaknya keluarga, hubungan mereka mulai dekat apalagi dengan sang adik. Sebagai cucu tertua Kuo merasa agak terbebani karena sering dikekang oleh keluarganya terutama nenek dari pihak papanya. Pendidikan di rumah pun sangat Jawa sekali.

\section{Bagaimanakah Konsep diri Anggota Komunitas Cosplay party?}

Berikut merupakan tabel konsep diri yang disusun berdasarkan pernyataan-pernyataan yang disampaikan oleh narasumber dan kesimpulan peneliti:

Tabel 1. Konsep Diri Narasumber

\begin{tabular}{|l|l|}
\hline \multicolumn{1}{|c|}{ Narasumber } & \multicolumn{1}{|c|}{ Konsep Diri } \\
\hline Ru & $\begin{array}{l}\text { Ramai, Semangat, Ceria, Tidak canggung/minder } \\
\text { "Gila", Rambut pendek, agak ikal, Berkacamata,Aktif, Sporty, Cuek, } \\
\text { Santai, Aneh, Moody, Tidak egois, Cinta kebebasan, Pemberontak, } \\
\text { Kritis, Tegas, Bertubuh kecil, Kekanak-kanakan, Manja, Suaranya } \\
\text { seperti anak kecil } \\
\text { Agak tertutup, Punya power syndrom, Apik, Apa adanya } \\
\text { Nrimo }\end{array}$ \\
\hline Dirck & $\begin{array}{l}\text { Cukup terbuka, Senang bercerita, Tidak canggung, Narsis } \\
\text { Ingin eksis, Hemat, Bertubuh kecil, Pendek, Kurus, "Ga jelas", } \\
\text { Namanya aneh, Kekanak-kanakan, Emosi labil, Gigi tonggos, } \\
\text { Pemalu, Susah mengungkapkan pikiran, Ceplas-ceplos, Anak } \\
\text { rumahan, "Gila", Suka memendam masalah, Tidak terencana, Santai, } \\
\text { Tidak disiplin, Cuek, Rambut agak gondrong, Tidak suka dibanding- } \\
\text { bandingkan }\end{array}$ \\
\hline Aira & $\begin{array}{l}\text { Kekanak-kanakan, Cengeng, Narsis, Tinggi 160, Berkacamata,Kulit } \\
\text { sawo matang, Rambut panjang, bergelombang, dan kering,, Moody, } \\
\text { Suka belanja, Spontan,,, Boros, Mudah dipengaruhi/terpengaruh, } \\
\text { Ramai, Senang bercerita, Mudah curhat, "Gila", Suka lari dari, } \\
\text { masalah, Nrimo, Serius dalam berhubungan,, Cuek } \\
\text { Senang jadi pusat perhatian, Tidak suka repot,Tidak tegas, Plinplan, } \\
\text { Keras kepala }\end{array}$ \\
\hline
\end{tabular}




\begin{tabular}{|l|l|}
\hline Kuo & $\begin{array}{l}\text { Diam, Tertutup, Agak sadis, Pemberontak, Nakal, Suka, berkelahi/ } \\
\text { tawuran, Tidak mau diperintah, Tidak bisa, dimarahi, Susah diberi } \\
\text { tahu, Gengsian, Anime banget, Aneh, Berani, Beda, Pelopor, Apa } \\
\text { adanya, Setia, Kulit coklat, Berkacamata, Rambut panjang, agak ikal, } \\
\text { diurai, jarang disisir, Cuek, Percaya diri, Eksis, Terbiasa sendiri } \\
\text { Narsis, Fleksibel, Menghargai waktu, Hemat, Sederhana } \\
\text { Suka makan, Blak-blakan/terus terang, Tegas, Keras kepala, } \\
\text { Bermuka dua }\end{array}$ \\
\hline
\end{tabular}

Untuk menyimpulkan apakah keempat narasumber peneliti memiliki konsep diri yang positif peneliti menggunakan karakteristik konsep diri positif dari D. E. Hamachek. Kesimpulan ini berdasarkan hasil pengamatan peneliti terhadap narasumber baik dari pernyataan maupun perilakunya. Konsep diri mereka peneliti anggap positif bila minimal sesuai dengan 6 karakteristik Hamachek.

\section{Tabel 2. Konsep diri narasumber berdasarkan karakteristik konsep diri positif Hamachek}

\begin{tabular}{|l|c|c|c|c|}
\hline \multicolumn{1}{|c|}{ Karakteristik } & Ru & Dirck & Aira & Kuo \\
\hline 1. $\begin{array}{l}\text { Ia meyakini betul-betul nilai-nilai dan prinsip- } \\
\text { prinsip tertentu serta bersedia mempertahankannya, } \\
\text { walaupun menghadapi pendapat kelompok } \\
\text { yang kuat. Tetapi, dia juga merasa dirinya cukup } \\
\text { tangguh untuk mengubah prinsip-prinsip itu bila } \\
\text { pengalaman dan bukti-bukti baru menunjukkan dia } \\
\text { salah. }\end{array}$ & $\mathrm{V}$ & & & $\mathrm{V}$ \\
\hline $\begin{array}{l}\text { Ia mampu bertindak berdasarkan penilaian yang } \\
\text { baik tanpa merasa bersalah yang berlebih-lebihan, } \\
\text { atau menyesali tindakannya jika orang lain tidak } \\
\text { menyetujui tindakannya. }\end{array}$ & $\mathrm{V}$ & & & $\mathrm{V}$ \\
\hline 3. & & & \\
$\begin{array}{l}\text { Ia tidak menghabiskan waktu yang tidak perlu } \\
\text { untuk mencemaskan apa yang terjadi besok, apa } \\
\text { yang telah terjadi di waktu yang lalu, dan apa yang } \\
\text { sedang terjadi di waktu sekarang. }\end{array}$ & $\mathrm{V}$ & $\mathrm{V}$ & $\mathrm{V}$ & $\mathrm{V}$ \\
\hline 4. & & & \\
$\begin{array}{l}\text { Ia memiliki keyakinan pada kemampuannya untuk } \\
\text { mengatasi persoalan, bahkan ketika ia menghadapi } \\
\text { kegagalan atau kemunduran. }\end{array}$ & $\mathrm{V}$ & & $\mathrm{V}$ \\
\hline 5. $\begin{array}{l}\text { Ia merasa sama dengan orang lain, sebagai manusia } \\
\text { tidak tinggi atau rendah, walaupun terdapat } \\
\text { perbedaan dalam kemampuan tertentu, latar } \\
\text { belakang keluarga, bentuk fisik, atau sikap orang } \\
\text { lain terhadapnya. }\end{array}$ & $\mathrm{V}$ & $\mathrm{V}$ & $\mathrm{V}$ & $\mathrm{V}$ \\
\hline
\end{tabular}




\begin{tabular}{|c|c|c|c|c|c|}
\hline & $\begin{array}{l}\text { Ia sangggup menerima dirinya sebagai orang yang } \\
\text { penting dan bernilai bagi orang lain, paling tidak } \\
\text { bagi orang-orang yang ia pilih sebagai sahabatnya. }\end{array}$ & $\mathrm{V}$ & $\mathrm{V}$ & $\mathrm{V}$ & $\mathrm{V}$ \\
\hline 7. & $\begin{array}{l}\text { Ia dapat menerima pujian tanpa berpura-pura } \\
\text { rendah hati, dan menerima penghargaan tanpa } \\
\text { merasa bersalah. }\end{array}$ & $\mathrm{V}$ & $\mathrm{V}$ & $\mathrm{V}$ & $\mathrm{V}$ \\
\hline 8. & $\begin{array}{l}\text { Ia cenderung menolak usaha orang lain untuk } \\
\text { mendominasinya. }\end{array}$ & $\mathrm{V}$ & $\mathrm{V}$ & & $\mathrm{V}$ \\
\hline 9. & $\begin{array}{l}\text { Ia sanggup mengaku kepada orang lain bahwa } \\
\text { ia mampu merasakan berbagai dorongan dan } \\
\text { keinginan, dari perasaan marah sampai cinta, } \\
\text { dari sedih sampai bahagia, dari kekecewaan yang } \\
\text { mendalam sampai kepuasan yang mendalam pula. }\end{array}$ & $\mathrm{V}$ & & $\mathrm{V}$ & $\mathrm{V}$ \\
\hline 10 & $\begin{array}{l}\text { Ia mampu menikmati dirinya secara utuh dalam } \\
\text { berbagai kegiatan yang meliputi pekerjaan, } \\
\text { permainan, ungkapan diri yang kreatif, } \\
\text { persahabatan, atau sekedar mengisi waktu. }\end{array}$ & $\mathrm{V}$ & $\mathrm{V}$ & $\mathrm{V}$ & $\mathrm{V}$ \\
\hline 11. & $\begin{array}{l}\text { Ia peka pada kebutuhan orang lain, pada kebiasaan } \\
\text { sosial yang telah diterima, dan terutama sekali } \\
\text { pada gagasan bahwa ia tidak bisa bersenang-senang } \\
\text { dengan mengorbankan orang lain. }\end{array}$ & $\mathrm{V}$ & $\mathrm{V}$ & $\mathrm{V}$ & $\mathrm{V}$ \\
\hline
\end{tabular}

Berdasarkan karakteristik konsep diri yang dikemukakan Hamachek, keempat narasumber penelitian ini memiliki konsep diri yang positif. $\mathrm{Ru}$ dan Kuo memiliki karakteristik pertama karena mereka berdua memiliki sifat yang tegas dan keras kepala. Keduanya yakin dengan kemampuan yang mereka miliki, selain itu mereka dapat dengan mudah mengungkapkan apa yang ada dalam pikiran, walaupun pendapat mereka tidak sesuai dengan pendapat orang banyak. Karakteristik yang kedua juga sesuai dengan $\mathrm{Ru}$ dan Kuo, karena keduanya sama-sama memiliki sifat pemberontak, mereka lebih memilih mengikuti kata hati.

Karakteristik ketiga sesuai dengan keempatnya, mereka semua tidak pernah mencemaskan sesuatu secara berlebihan karena mereka memiliki sifat cuek dan cenderung mengalir seperti air dalam memandang sesuatu. Karaktristik keempat sesuai deengan $\mathrm{Ru}$ dan Kuo, mereka sangat percaya diri dengan kemampuannya, masalah nantinya akan gagal atau tidak toh mereka sudah puas karena semuanya dikerjakan dengan kemampuan sendiri, misalnya ketika membuat aksesoris untuk cosplay. Karakteristik kelima juga dimiliki oleh keempatnya, mereka merasa setara dengan orang lain, mereka sadar bahwa setiap pribadi memiliki keunikan yang berbedabeda, jadi tidak ada salahnya jika mereka berbeda dari orang lain. Dirck 
yang secara fisik (maaf) bergigi tonggos, dan Ru yang berbadan kecil merasa hal itu sebagai kenyataan yang harus diterima secara positif. Mereka juga sama-sama sanggup menerima dirinya sebagai orang yang penting dan bernilai bagi orang lain terutama sahabat-sahabat mereka, sesuai dengan karakteristik keenam.

Bagi mereka sahabat merupakan salah satu bagian penting dalam hidup mereka, karena sahabat adalah orang yang mampu menerima diri mereka apa adanya, teman berbagi dikala susah dan senang, hubungan mereka juga saling timbal balik. Walaupun kadang muka merona merah ketika mendapat pujian tapi mereka tidak berpura-pura rendah hati karena mereka khususnya $\mathrm{Ru}$ dan Kuo memiliki keyakinan akan kemampuan mereka, bukannya Dirck dan Aira tidak memiliki keyakinan tersebut namun Ru dan Kuo memiliki kepercayaan diri yang lebih tinggi dibanding mereka berdua.

$\mathrm{Ru}$, Dirck, dan Kuo cenderung menolak dominasi orang lain terhadap dirinya sedangkan Aira lebih mudah untuk dipengaruhi atau terpengaruh oleh orang lain. Bahkan Ru dan Kuo terang-terangan mengaku sebagai pemberontak, Ru juga sempat mengungkapkan bahwa ia lebih memilih untuk diam bila ada yang mendominasi tapi bila ada satu kesempatan dirinya dapat mendominasi semua harus tunduk padanya. Ru, Aira, dan Kuo lebih mudah mengungkapkan perasaannya dibanding Dirck yang lebih suka memendam sesuatu dan sulit untuk mengungkapkan apa yang ada dalam pikirannya mungkin karena mereka bertiga walau sekeras dan secuek apapun, perasaan mereka cenderung lebih peka daripada laki-laki.

Keempat narasumber penelitian ini mampu menilmati dirinya secara utuh sesuai karakteristik kesepuluh. Dalam menghadapi sesuatu mereka cenderung santai, dan merasa nyaman dengan keberadaan diri mereka sehingga dapat menerima diri dengan apa adanya. Karakteristik kesebelas juga dimiliki semuanya tapi yang paling menonjol adalah $\mathrm{Ru}$, karena ia sangat benci dengan orang yang egois sehingga sedapat mungkin ia tidak berlaku egois terhadap orang lain.

Sejauh yang saya amati mereka sudah merasa nyaman dengan diri mereka, walaupun dalam hidup mereka tidak semuanya ideal mereka mampu menikmati dan menerima diri mereka apa adanya. Mereka juga selalu positif terhadap pandangan orang mengenai dirinya. Mereka juga mampu menceritakan seperti apa diri mereka dengan lancar baik secara langsung maupun tersirat. 


\section{Bagaimanakah Mereka Mengekspresikan Diri dalam Cosplay Event dan Bagaiman a Pula Ekspresi Diri Mereka dalam Kehidupan Sehari-Hari?}

1. Ru Hanya Membuat kostum yang disukai secara pribadi tanpa pengaruh teman. Sejauh ini ia telah memiliki tiga kostum. Uang sakunya yang pas-pasan menuntut $\mathrm{Ru}$ menjadi lebih kreatif dalam membuat kostum agar bisa semirip mungkin dengan aslinya. Karena keterbatasan tersebut biasanya $\mathrm{Ru}$ sering memodifikasi sendiri kostumnya, kadang bila mengalami kesulitan $\mathrm{Ru}$ juga minta bantuan teman-teman komunitas. Ru tidak menetapkan dana khusus untuk membuat kostum. Dalam membuat satu kostum $\mathrm{Ru}$ paling hanya menghabiskan uang sekitar Rp 200,000an. Uang itu sebagian dari hasil tabungannya tapi bila ada kekurangan Ru biasa "menodong" mamanya. Dalam mempersiapkan kostum untuk suatu event biasanya tergantung mood, terkadang walaupun sudah tahu dua atau tiga bulan sebelumnya $\mathrm{Ru}$ dan teman-teman sering masih bersantai dan baru "sadar" saat mendekati deadline barulah mereka buru-buru mencari bahan dan membuat kostum serta aksesoris-aksesoris pendukungnya. Ru berusaha tampil semirip mungkin dengan kostum dan perilaku tokoh yang diperankannya. Dalam keseharian Ru tidak merasakan perbedaan apapun sejak bergabung dengan cosplay party. Ru merasakan bahwa ketika bercosplay ia menjadi orang yang lain dari kesehariannya.

2. Mengenai cosplay Dirck mengaku baru mulai menggelutinya tahun ini. Awalnya Dirck hanya melihat-lihat saja, ia merasa tertarik kemudian mulai mencoba dan akhirnya jadi ketagihan. Pertama kali Dirck ikut cosplay ia lebih memilih menggunakan kostum gothic karena biayanya cenderung lebih murah, memakai baju seadanya, hanya saja penampilannya lebih difokuskan pada make-up yang gelap. Keterbatasan uang saku membuat Dirck lebih memilih meminjam aksesoris dari teman-temannya. Dalam mengikuti cosplay bujang yang tadinya mengidolai Cosplay Party ini lebih kepada memuaskan dirinya yang ingin selalu eksis, dan menyalurkan kenarsisannya. Setiap kali sedang bercosplay ria, Dirck sering sekali diajak berfoto, ia tidak pernah merasa keberatan karena baginya hal tersebut sangat menyenangkan. Dalam bercosplay Dirck tampil seolah sebagai selebriti penting dan menyesuaikan tingkah lakunya selayaknya aktor yang menjaga imej dan merasa menjadi pusat perhatian.

3. Aira mulai suka hal yang berhubungan dengan Jepang sejak SMP, 
awalnya ia sering nonton anime seperti Samurai $X$ dan juga sudah mulai ada dorama-dorama (patung kecil tokoh anime). Sebelumnya Aira sempat suka dengan hal-hal yang berbau mandarin tapi setelah melihat Jepang ia langsung berpindah ke lain hati dan akhirnya berlanjut hingga saat ini. Selain anime, Aira juga suka komik-komiknya bahkan dulu ia sering membeli namun ketika mulai ikut cosplay ia lebih memilih untuk meminjam komik dari teman dan uangnya ditabung untuk mempersiapkan kostum cosplay. Aira juga sangat kagum dengan tradisionalisme orang Jepang, walaupun mereka merupakan negara yang sudah sangat maju tapi masih menjunjung tinggi budaya dan tradisinya. Motivasi Aira ikut cosplay sebenarnya karena ia ingin difoto orang-orang. Awalnya ia iri dengan para cosplayer karena sering mendapat perhatian dari orang-orang. Seringkali mereka diajak berfoto, kenalan, diminta tandatangan, dan kadang bisa masuk ke majalah anime. Diluar panggung cosplay Aira tampil dan berperilaku apa adanya dengan gayanya yang santai.

4. Kuo Pertama ikut cosplay di Jakarta. Awalnya sempat merasa takut karena harus naik ke atas panggung dan memeragakan apa yang ia bisa. Namun dengan modal kepercayaan dirinya lama-kelamaan ia menjadi terbiasa. Sejauh ini dana yang dikeluarkan untuk membuat kostum paling banyak sekitar Rp 100.00,- Kuo sering memanfaatkan bahanbahan sisa di rumahnya, ia juga sedikit-sedikit belajar menjahit pada sang mama untuk pengiritan. Selain mendesain sendiri kadang juga ia sering merombak baju-bajunya yang lama. Kesukaannya menggambar juga membuat Kuo dipercaya teman-temannya untuk mendesain kaos atau jaket angkatan.

Bila sedang bercosplay Kuo berusaha menjadi tokoh tersebut, bagaimana sifatnya, cara bicara, berjalan, dan sebagainya ia tiru. Dalam memilih tokoh untuk cosplay kadang ia tidak mencari tokoh yang karakternya sesuai dengan dirinya agar lebih menantang. Kalau seharihari ia merasa tampil dan berperilaku biasa saja. Namun demikian dalam interaksi sehari-hari dengan lingkungannya, Kuo menjadi lebih percaya diri dan lebih berani mengungkapkan sudut pandangnya tentang berbagai isyu yang muncul di kampus tanpa takut ditertawakan atau dianggap berbeda. 


\section{Bagaimanakah Pengaruh Nilai-Nilai Cosplay Terhadap Konsep Diri Anggota}

\section{Anggota Komunitas?}

1. Ru menemukan kebebasan bereskpresi, keberanian berinovasi, keberanian mencoba, dan penerimaan perbedaan sebagai hal terpenting dalam komunitas cosplay. Hal ini meneguhkan kepercayaan Ru bahwa manusia dapat berkreasi, memodifikasi dan menata hidup sesuai karakteristik masing-masing.

2. Bagi Dirck semua yang berbau Jepang menarik mulai dari anime, bahasa, musik, film, dan sebagainya. Dirck juga mengagumi kedisiplinan orang Jepang yang selalu teratur dan rapi, menurutnya hal tersebut sangat baik bila bisa ditiru oleh orang Indonesia. Dirck sendiri menilai sikap bersungguh-sungguh dari orang Jepang sangat penting. Dari Cosplay Dirck meyakini bahwa orang harus berani mengekspresikan diri. Tiap orang adalah unik dan harus diperlakukan secara hormat.

3. Aira Merasakan adanya keyakinan dan semangat untuk menghargai karya orang lain, mengelola dan mengekspresikan diri seperti yang diinginkan, dan pembangunan harga diri. Inilah nilai-nilai yang dikembang komunitas cosplay yang membuat Ru merasa cocok didalamnya.

4. Bagi Kuo Cosplay menanamkan nilai kepercayaan diri, kerjasama, dan keberanian berekspresi dan bereksistensi. Tapi nilai-nilai yang terkandung dalam cosplay sendiri sebenarnya cocok dengan konsep diri Kuo. Lewat cosplay kuo mulai berani mengeskpresikan diri secara berbeda dan percaya untuk berbagi tugas dengan orang lain.

\section{Catatan Penutup}

Penelitian ini membahas tentang empat hal pokok dari anggota komunitas Cosplay Party yakni; Latar belakang kehidupan, konsep diri, bagaimana mereka berekspresi dalam event cosplay dan kehidupan keseharian, serta pengaruh nilai-nilai cosplay pada diri mereka. Dari temuan lapangan dapat disimpulkan bahwa; :

1. Informan memiliki latar belakang kehidupan yang beragam. Namun bagi informan Keluarga dan teman merupakan significan others yang memiliki pengaruh yang besar dalam pembentukan konsep diri mereka.

2. Berdasarkan karakteristik konsep diri yang dikemukakan Hamachek, 
keempat narasumber penelitian ini memiliki konsep diri yang positif. Mereka sudah merasa nyaman dengan diri mereka, walaupun dalam hidup mereka tidak semuanya ideal mereka mampu menikmati dan menerima diri mereka apa adanya. Mereka juga selalu positif terhadap pandangan orang mengenai dirinya.

3. Keterlibatan narasumber dengan costume player sama-sama diawali dengan kesukaan mereka akan anime atau film kartun Jepang sejak kecil. Hal inilah yang membuat mereka tertarik dengan hal-hal yang berhubungan dengan Jepang dan pada akhirnya mencoba cosplay. Cara narasumber mengekspresikan diri ternyata berbeda antara kehidupan sehari-hari dengan ketika mereka ber-cosplay. Saat ber-cosplay mereka memainkan peranan sebagai orang lain yang berbeda dengan keseharian mereka. Ini artinya nilai-nilai yang mengatur perilaku mereka berbeda antara ketika berada dalam komunitas dengan diluar komunitas. Narasumber melakukan mengelolaan kesan dalam mempresentasikan diri. Jadi diri yang ditampilkan dalam ber-cosplay adalah the presenting self.

4. Narasumber bergabung dengan cosplay karena adanya kesesuaian atau kesamaan nilai antara mereka dengan fenomena cosplay. Keempat narasumber penelitian ini menjadikan komunitas sebagai kelompok rujukan namun mereka tidak menyesuaikan diri dengan segala nilai yang diusung cosplay. Narasumber menerima dan mengokohkan nilainilai yang diusung cosplay bila sebelumnya mereka meyakini nilai itu sebagai bagian konsep diri mereka. Nilai-nilai tersebut diantaranya keberanian berekspresi, inovasi, dan penghargaan terhadap perbedaan

5. Pandangan orang lain tidak dijadikan sebagai sumber primer data tentang dirinya. Mereka memiliki keyakinan yang tinggi tentang pengetahuan akan dirinya sendiri. Mereka merasa bagaimanapun juga merekalah yang paling mengenal dirinya sehingga pandangan orang lain tidak terlalu berpengaruh bagi sumber primer data tentang diri mereka. Hal ini berlawanan dengan teori looking-glass self, Charles Horton Cooley yang berpendapat bahwa konsep-diri individu secara signifikan ditentukan oleh apa yang ia pikirkan tentang pikiran orang lain mengenai dirinya, jadi menekankan pentingnya respons orang lain yang ditafsirkan secara subyektif sebagai sumber primer data mengenai dirinya.

Kesimpulan diatas diambil dari jumlah informan yang masih terbatas. Hasil kesimpulan ini belum dapat digunakan sebagai dasar pengkonstruksian model-model konsep diri orang-orang yang menjadi 
anggota komunitas cosplay. Untuk itu penelitian lebih lanjut dengan menggunakan pendekatan fenomenologi sangat dianjurkan.

\section{Daftar Pustaka}

Abdullah, Irwan. 2006. Konstruksi dan Reprosukdi Kebudayaan. Yogyakarta: Pustaka Pelajar.

Agustiani, Hendriati. 2006. Psikologi Perkembangan: Pendekatan Ekologi Kaitannya Dengan

Konsep Diri dan Penyesuaian Diri Pada Remaja. Bandung: PT Refika Aditama.

Barker, Chris. 2004. Cultural Studies Teori dan Praktek. Yogyakarta: Kreasi Wacana.

Burns, R.B. 1993. Konsep Diri. Jakarta: Arcan.

Creswell, John. W. 1998. Qualitative Inquiry and Research Design Choosing Among Five Traditions. California: Sage Publications.

Harre, Rom, \& Roger Lamb. Ensklopedi Psikologi. 2001. Jakarta: Penerbit Arcan

Kato, Hidetoshi. 1973. Japanese Popular Culture. Westport, Connecticut: Greenwood Press.

Mahindria, Lucky Helmi. 2007. Konsep Diri Anggota Cosplay Party Bandung. Skripsi. Bandung: Fikom Unpad

Marshall, Gordon. 1998. Dictionary of Sociology. Oxford: Oxford University Press.

Moustakas, Clark. 1994. Phenomenological Research Methods. USA: Sage .

Mulyana, Deddy. 2004. Metodologi Penelitian Kualitatif. Bandung: Remaja Rosdakarya.

Powers, R.G. \& Hidetoshi Kato. 1989. Handbook of Japanese Popular Culture. London: Greenwood Press.

Roman, Annete. 1999. Japan Edge: The Insiders's Guide to Japanese Pop Subculture. San Francisco: Cedente Books.

Srinati, Dominic. 2003. Popular Culture. Yogyakarta: Bentang

Sullivan, John. Et. Al. 1996. Key Concepts in Communication and Cultural Studies. New York: Routledge.

Watson, J. \& Anne Hill. 2000. Dictionary of Media \& Communication Studies. London: Arnold. 


\section{Sumber Internet lain:}

\section{Harian Umum Kompas}

Artikel 'Bebas Merdeka dengan Harajuku'. http://www.kompas.com/ kompas cetak/0609/24/kehidupan/2971944.htm

Artikel 'Mengekspor Mode dari Harajuku'. http://www.kompas.com/ kompas cetak/0604/16/urban/2586919.htm

Harian Umum Pikiran Rakyat. Tanggal 16 Maret 2004. http://www. Pikiran_Rakyat.com/ 